\title{
The effect of additional supplementation of vitamin $E$ and zinc on endocrine and metabolic changes in dairy cows during peripartal period
}

\author{
Anjali Aggarwal', and Gulab Chandra ${ }^{2 *}$ \\ ${ }^{\prime}$ Dairy Cattle Physiology Division, National Dairy Research Institute, Karnal, Haryana, India \\ ${ }^{2}$ Department of Veterinary Physiology and Biochemistry, Sardar Vallabhbhai Patel University of Agriculture \\ and Technology, Meerut, Uttar Pradesh, India
}

\begin{abstract}
AGGARWAL, A., G. CHANDRA: The effect of additional supplementation of vitamin $E$ and zinc on endocrine and metabolic changes in dairy cows during peripartal period. Vet. arhiv 88, 733-748, 2018.
\end{abstract}

\section{ABSTRACT}

The objective of this study was to measure the effect of vitamin E (Vit-E) and zinc (Zn) supplements on endocrine and metabolic changes in peripartum cows. Thirty-two crossbred (Holstein Friesian $\times$ Tharparkar) cows were selected 60 days before the expected date of calving. The cows were arbitrary allocated into 4 groups $(\mathrm{n}=8)$, namely: the control, $\mathrm{T} 1, \mathrm{~T} 2$, and T3. The feeding schedule was similar in all the groups except that in $\mathrm{T} 1$, T2, and T3 $60 \mathrm{mg} \mathrm{Zn/kg} \mathrm{DM,} 1000 \mathrm{IU}$ Vit-E and $60 \mathrm{mg} / \mathrm{kg}+1000 \mathrm{IU} \mathrm{Zn}+$ Vit-E were additionally added, respectively, from day 60 pre-calving to day 60 post-calving. Blood samples were taken on days $60,45,30,15$, and 7 before and after the expected day of calving and on the day of calving. Before calving, the cows showed a decrease in plasma leptin, insulin, glucose, Vit-E, and Zn levels, and an increase in plasma non-esterified fatty acid level. However, increases in plasma leptin, insulin, glucose, Vit-E, and $\mathrm{Zn}$ and a decrease of plasma nonesterified fatty acid were observed after calving. After calving, group T3 had higher $(\mathrm{P}<0.05)$ plasma leptin, insulin, and glucose concentrations than all the other groups. Plasma Vit-E levels were higher $(\mathrm{P}<0.05)$ in groups T2 and T3; however, the $\mathrm{Zn}$ level was higher $(\mathrm{P}<0.05)$ in groups T1 and T2. Milk yield was observed to be higher $(\mathrm{P}<0.05)$ in $\mathrm{T} 3$ than in the control and groups $\mathrm{T} 1$ and $\mathrm{T} 2$. The reduction in leptin, insulin, glucose, Vit-E, and Zn during peripartum was ameliorated by Vit-E and Zn supplementation.

Key words: leptin; insulin; vitamin E; zinc; crossbred cows

\section{Introduction}

The peripartum period is recorded as one of the most crucial periods for the production cycle in dairy cattle because of the metabolic changes that occur during this

\footnotetext{
${ }^{*}$ Corresponding author:

Gulab Chandra, Department of Veterinary Physiology and Biochemistry, Sardar Vallabhbhai Patel University of Agriculture and Technology, Meerut, Uttar Pradesh, India, Phone: +91 790663 5166; E-mail: gulabdrvet@gmail.com
} 
period (PEZESHKI et al., 2010). During this period, cows experience a declination in feed intake and a degree of negative energy balance, which is linked to metabolic and hormonal changes (GRUMMER et al., 2004). These changes are generally linked with an increased risk of metabolic and production associated diseases (FRIGGENS et al., 2004). Feeds and fodder may not provide for appropriate blood levels of Vit-E and $\mathrm{Zn}$ around parturition (UNDERWOOD and SUTTLE, 2001). Therefore, during the dry period and the early phase of lactation the extra addition of micronutrients to the feed is required to prevent metabolic and production related diseases, before and after calving. Vitamin $\mathrm{E}$ and $\mathrm{Zn}$ are necessary for the health and productive performance of dairy cows (HERDT and STOWE, 1991). These micronutrients are cellular antioxidants and required for the good function of the immune system (WEISS, 2002). Leptin is a protein hormone synthesized by adipose tissues and participates in the regulation of feed intake, energy balance, fertility, and immune functions (AHIMA and FLIER, 2000). The negative energy balance around parturition causes a reduction in circulating levels of leptin (BLOCK et al., 2001). During peripartum, a decline was shown in dairy cows in the concentration of plasma leptin (THORN et al., 2008). A linear relationship was observed in well-fed lactating dairy cows between plasma leptin and body condition score (BCS) (BLOCK et al., 2001). Growth hormones increase the sensitiveness of adipose tissue to catecholamines (BAUMAN and VERNON, 1993) causing lypolysis that elevates blood concentrations of non-esterified fatty acid (NEFA).

There is no literature available on the effect of additional Vit-E and $\mathrm{Zn}$ supplementation on hormonal and metabolic changes in crossbred cows. Therefore, the present study was undertaken to find out the effect of Vit- $\mathrm{E}$ and $\mathrm{Zn}$ and the combination of these supplementations on hormonal and metabolic changes in peripartum crossbred cows.

\section{Materials and methods}

The study was permitted by the Animal Ethics Committee of the National Dairy Research Institute, Karnal, Haryana, India (under CPCSEA, Article No. 13).

Experimental design and treatments. A total of thirty-two pregnant Karan Fries crossbred (Holstein Friesian $\times$ Tharparkar) cows with average body weight $(510 \pm 12.58$ $\mathrm{kg})$, BCS $(3.12 \pm 0.09)$, parity $(2.8 \pm 057)$ and milk yield $(\mathrm{MY}, 15.90 \pm 1.28 \mathrm{~kg})$ were randomly distributed into four groups $(\mathrm{n}=8)$, as follows: control group (receiving a basal diet devoid of supplemental $\mathrm{Zn}$ and Vit-E); group T1 (supplemented with $60 \mathrm{mg} \mathrm{Zn/kg}$ DM); group T2 (supplemented with 1000 IU Vit-E); and group T3 (supplemented with 60 $\mathrm{mg} \mathrm{Zn/kg}+1000$ IU Vit-E). The supplementation was continued from day 60 prepartum to day 60 postpartum. Precisely weighed Vit-E and $\mathrm{Zn}$ were mixed with a small amount of concentrate and fed individually. Vitamin $\mathrm{E}$ and $\mathrm{Zn}$ were supplemented in the form of DLalpha-tocopheryl acetate (Xi' an Healthful Biotechnology, Hi-New Zone, Xi'an, China) 
and zinc sulphate heptahydrate $\left(\mathrm{ZnSO}_{4} \cdot 7 \mathrm{H} 2 \mathrm{O}\right.$, Luancheng Terife Agricultural Materials, Shijiazhuang, Hebei Province, China), respectively. The basal diet provided $45 \mathrm{mg} / \mathrm{kg}$ $\mathrm{DM}$ and $190 \mathrm{IU} \mathrm{Zn}$ and Vit-E, respectively (in total)/cow/day. The nutrient requirement of experimental cows was fulfilled by feeding total mixed ration (TMR) NRC (2001). The ingredients and nutrient compositions of TMR fed during the experimental period are presented in Table 1.

Table 1. Ingredients and nutrient composition of diets fed during the experimental period

\begin{tabular}{|l|c|}
\hline Nutrient composition of basal diets & Content (\% DM basis) \\
\hline Berseem fodder & 18.0 \\
\hline Wheat straw & 20.1 \\
\hline Ground yellow maize & 30.0 \\
\hline Groundnut cake & 15.4 \\
\hline Wheat bran & 6.8 \\
\hline Rice bran & 7.9 \\
\hline Mineral mixture and vitamins premix ${ }^{1}$ & 0.9 \\
\hline Salt & 0.3 \\
\hline Zinc sulphate heptahydrate ${ }^{2}$ & 0.2 \\
\hline DL-alph-tocopheryl acetate & 0.4 \\
\hline Chemical composition of basal diets & Content (DM basis) \\
\hline Dry matter, \% & 74.5 \\
\hline Organic matter, \% & 79.4 \\
\hline Crude protein, \% & 18.0 \\
\hline Crude fiber, \% & 24.0 \\
\hline Total ash, \% $\%$ & 9.3 \\
\hline NDF, \% & 39.9 \\
\hline ADF, \% & 29.7 \\
\hline Zinc, mg/kg & 49.54 \\
\hline DL-alpha-tocopheryl acetate, IU & 190 \\
\hline
\end{tabular}

'Premix composition per kilogram: vitamin A 500,000 IU, vitamin D3 10,000 IU, vitamin E $100 \mathrm{mg}$, Ca 190,000 mg, P 90,000 mg, Na 50,000 mg, Cu 300 mg, Fe 3,000 mg, Mn 2,000 mg, I 100 mg, Co 100 mg, Se 1 mg, Mg $19,000 \mathrm{mg}$, and BHT antioxidant $3,000 \mathrm{mg}$

${ }^{2}$ Supplemental zinc sulfate heptahydrate $(0.20 \%)$ and DL-alph-tocopheryl acetate $(0.40 \%)$ were substituted for ground yellow maize to provide $60 \mathrm{mg} / \mathrm{kg} \mathrm{Zn}$ and $1000 \mathrm{IU}$ Vitamin E.

Sampling. Blood was sampled from all cows on days $60,45,30,15$, and 7 before the expected day of calving, on the day of calving and on days $7,15,30,45$, and 60 after calving. Blood was drawn from the jugular vein using sterile heparinised Vacutainer systems (BD Vacutainer ${ }^{\mathrm{TM}}$, UK). All samples were collected between 6 and 7 a.m. before giving feed and water. The samples were kept at 6 to $10{ }^{\circ} \mathrm{C}$ before they reached the 
laboratory and were centrifuged at $1,200 \times \mathrm{g}$ at $4{ }^{\circ} \mathrm{C}$ for $20 \mathrm{~min}$. Plasma was separated from packed cells and analyzed for leptin, insulin, glucose, NEFA, Vit-E, and Zn. Body condition was scored on the day of blood collection by a 5-point scale method (EDMONDSON et al., 1989). The cows were milked three-times daily and milk weights were recorded daily up to day 60 of lactation.

Laboratory analysis. Daily feeds offered and residue left was recorded, to determine the dry matter intake (DMI). Dry matter, organic matter, crude protein, ether extract, and total ash of the basal diet were determined according to AOAC (1995). Neutral detergent fiber and acid detergent fiber contents were estimated by the detergent method, as described by VAN SOEST et al. (1991). Estimation of Vit-E in feed and plasma samples was carried out by Waters HPLC on a C-18 column Model 510 (Milford, MA, USA) using the extraction procedure of CHAWLA and KAUR (2001). The solvent system used was acetonitrile and HPLC water in a ratio of 95:5. Plasma and feed zinc content was determined by atomic absorption spectrophotometer (AAS) (Model Z-5000, Polarized Zeeman Atomic Absorption Spectrophotometer; Hitachi High-Technologies Corporation, Tokyo, Japan). The procedures were followed as described in the AAS (1988) manual.

Concentrations of leptin in the plasma were estimated using bovine leptin ELISA kits (Cusabio Biotech Co., Ltd. China). Intra and inter assay coefficients of variation were $4.55 \%$ and $8.45 \%$, respectively. The sensitivity of the assay for leptin was $1.56 \mathrm{ng} /$ $\mathrm{mL}$. Plasma insulin was assayed by bovine insulin ELISA kits (Endocrine Technologies, New York, USA). The intra and inter-assay coefficients of variation for insulin were $3.54 \%$ and $8.77 \%$, respectively. The sensitivity of the assay for insulin was $0.2 \mathrm{ng} / \mathrm{mL}$. Plasma glucose concentrations were measured by enzymatic assays, using glucose colorimetric assay kits (Cayman's Chemical Company, Ann Arbour, Michigan, USA). The volumes of the reagents and samples were modified to allow the assays to be conducted in 96-well ELISA plates, and absorbance was measured by an Infinite ${ }^{\circledR} 200$ PRO microplate reader (Tecan group Ltd, Mannedorf, Switzerland). Plasma concentration of NEFA was evaluated by bovine NEFA ELISA kits (Cusabio Biotech Co., Ltd. China). The intra and inter assay coefficients of variation for NEFA were $4.34 \%$ and $9.32 \%$, respectively. The sensitivity of the assay for plasma NEFA was $10 \mu \mathrm{mol} / \mathrm{L}(\mu \mathrm{M})$.

Statistical analyses. Results for DMI, plasma hormones (leptin and insulin), and energy metabolites (glucose and NEFA) were analyzed using the MIXED procedure, as repeated measures of SPSS (SPSS Inc., Chicago, IL, USA). The first model was used to analyse sampling day effect, treatment effect (Vit-E and Zn supplementation) and their interaction:

$$
Y i j k=\mu+T i+D j+(T \times D) i j+e i j k
$$


where, Yijk is the dependent variable; $\mu$ is the population mean; $T i$ is the effect of the treatment (Vit-E and Zn supplementation) ( $i=$ control, T1, T2, and T3); $D j$ is the effect of day of sampling $(j=-60,-45,-30,-15,-7,0,7,15,30,45$, and $60 \mathrm{~d})$ with day as a repeated factor; $(T \times D) i j$ is an interaction parameter corresponding to treatment $i$ and day $j$; and $e i j k$ is the residual error.

The second model was used to analyse the effect of physiological phase (pre and post-partum), treatment effect (Vit-E and Zn supplementation) and their interaction. Day of parturition (0) was considered as a postpartum variable:

$$
\text { Yijk }=\mu+T i+P j+(T \times P) i j+e i j k
$$

where Yijk is the dependent variable; $\mu$ is the population mean; $T i$ is the effect of the treatment (Vit-E and $\mathrm{Zn}$ supplementation) ( $i=$ control, T1, T2, and T3); Pi is the effect of the physiological phase $\{j=$ pre-partum $(-60,-45,-30,-15,-7 \mathrm{~d})$ and post-partum $(0$, $7,15,30,45$, and $60 \mathrm{~d})\}$ with physiological phase as a repeated factor. $(T \times P) i j$ is an interaction parameter corresponding to treatment $i$ and physiological phase $j$; and eijk is the residual error.

The model included the group and day (or physiological phase), and their interaction as fixed effects, and the animal within the group as the random effect. Comparison of the means of different groups and day (or physiological phase) was carried out using Duncan's Multiple Range Test.

\section{Results}

Changes in BCS among the control and treatment groups are depicted in Fig. 1. The control group showed the maximum $(\mathrm{P}<0.05) \mathrm{BCS}$ reduction from $60 \mathrm{~d}$ pre-partum to $60 \mathrm{~d}$ post-partum in comparison to cows receiving a basal diet supplemented with Vit-E and $\mathrm{Zn}$. The leptin and insulin concentrations decreased towards calving and the lowest were observed on the day of parturition. They remained low after calving (Fig. 2 and 3). The $\mathrm{Zn}+$ Vit-E supplemented group had higher plasma leptin $(\mathrm{P}<0.05)$ and insulin $(\mathrm{p}=$ $0.999)$ pre-calving in comparison to their concentrations observed at post-calving (Table $2)$. Leptin was positively correlated to insulin $(r=0.42, P<0.05)$ and glucose $(r=0.56$, $\mathrm{P}<0.05)$, and negatively correlated to NEFA $(\mathrm{r}=0.52, \mathrm{P}<0.05)$.

Plasma glucose concentrations began to decrease steadily from $60 \mathrm{~d}$ pre-calving and reached the minimum on the day of calving (Fig. 4). After calving, glucose concentrations started to increase slowly (Fig. 4). This change resulted in lower $(\mathrm{P}<0.05)$ values after calving, compared with those observed before calving in all the groups (Table 2). Plasma concentrations of NEFA began to increase slightly from $30 \mathrm{~d}$ before calving and reached maximum levels on $7 \mathrm{~d}$ post-calving, were higher $(\mathrm{P}<0.05)$ in the control than in the $\mathrm{Zn}$, Vit-E, and $\mathrm{Zn}+$ Vit-E supplemented groups of cows (Fig. 5). After $7 \mathrm{~d}$ post-calving NEFA concentrations started to decrease in all the groups, but the decrease was lower in the control followed by the Zn, Vit-E, and Zn+Vit-E supplemented groups (Fig. 5). 
A. Aggarwal and G. Chandra: Hormonal, metabolic and productive performance of cows

The pre-calving plasma NEFA concentration was higher $(\mathrm{P}<0.05)$ than its post-calving concentration in all four groups of crossbred cows (Table 2). The DMI during the precalving period was lower $(\mathrm{P}<0.05)$ than its values observed during post-calving in all four groups (Table 2).

Table 2. Plasma concentrations of leptin, insulin, growth hormone, glucose, and non-esterifies fatty acid (NEFA) during peripartum in vitamin E and zinc supplemented and non-supplemented groups

\begin{tabular}{|c|c|c|c|c|c|c|c|c|}
\hline \multirow[b]{2}{*}{ Parameters } & \multicolumn{4}{|c|}{ Group } & \multirow[b]{2}{*}{ SEM } & \multicolumn{3}{|c|}{$P$ value } \\
\hline & Control & $\mathrm{T} 1$ & $\mathrm{~T} 2$ & $\mathrm{~T} 3$ & & Group & Day & $\begin{array}{c}\text { Group } \times \\
\text { Day }\end{array}$ \\
\hline \multicolumn{9}{|c|}{ Leptin $(\mathrm{ng} / \mathrm{mL})$} \\
\hline Pre-calving & $4.75^{\mathrm{a}}$ & $4.59^{\mathrm{a}}$ & $4.81^{\mathrm{a}}$ & $4.93^{\mathrm{a}}$ & 0.23 & $<0.001$ & $<0.001$ & $<0.001$ \\
\hline Post-calving & $3.17^{\mathrm{bB}}$ & $3.36^{\mathrm{bB}}$ & $3.98^{\mathrm{bA}}$ & $4.05^{\mathrm{bA}}$ & 0.19 & & & \\
\hline \multicolumn{9}{|c|}{ Insulin (ng/mL) } \\
\hline Pre-calving & $0.63^{\mathrm{a}}$ & 0.61 & 0.65 & 0.69 & 0.03 & $<0.001$ & $<0.001$ & 0.099 \\
\hline Post-calving & $0.52^{\mathrm{b}}$ & 0.53 & 0.61 & 0.61 & 0.03 & & & \\
\hline \multicolumn{9}{|c|}{ Glucose (mM) } \\
\hline Pre-calving & $3.00^{\mathrm{a}}$ & $3.12^{\mathrm{a}}$ & $3.11^{\mathrm{a}}$ & $3.24^{\mathrm{a}}$ & 0.10 & $<0.001$ & $<0.001$ & 1.000 \\
\hline Post-calving & $2.47^{\mathrm{bB}}$ & $2.75^{\mathrm{bA}}$ & $2.75^{\mathrm{bA}}$ & $3.01^{\mathrm{bA}}$ & 0.13 & & & \\
\hline \multicolumn{9}{|l|}{$\operatorname{NEFA}(\mu \mathrm{M})$} \\
\hline Pre-calving & $168.57^{\mathrm{b}}$ & $150.07^{b}$ & $149.06^{\mathrm{b}}$ & $136.32^{\mathrm{b}}$ & 14.88 & $<0.001$ & $<0.001$ & 0.425 \\
\hline Post-calving & $321.34^{\mathrm{aA}}$ & $269.99^{\mathrm{aB}}$ & $272.47^{\mathrm{aB}}$ & $198.25^{\mathrm{aB}}$ & 23.27 & & & \\
\hline \multicolumn{9}{|c|}{ Vitamin $\mathrm{E}(\mu \mathrm{g} / \mathrm{mL})$} \\
\hline Pre-calving & $2.73^{\mathrm{a}}$ & $2.69^{a}$ & $2.76^{\mathrm{a}}$ & $2.77^{\mathrm{a}}$ & 0.04 & $<0.001$ & $<0.001$ & 0.078 \\
\hline Post-calving & $2.05^{\mathrm{bB}}$ & $2.10^{\mathrm{bB}}$ & $2.39^{\mathrm{bA}}$ & $2.41^{\mathrm{bA}}$ & 0.05 & & & \\
\hline \multicolumn{9}{|l|}{ Zinc $(\mu \underline{g} / \mathrm{mL})$} \\
\hline Pre-calving & $1.43^{\mathrm{a}}$ & $1.45^{\mathrm{a}}$ & $1.44^{\mathrm{a}}$ & $1.45^{\mathrm{a}}$ & 0.10 & 0.001 & $<0.001$ & 0.097 \\
\hline Post-calving & $0.93^{\mathrm{bB}}$ & $1.19^{\mathrm{bA}}$ & $0.95^{\mathrm{bB}}$ & $1.20^{\mathrm{bA}}$ & 0.10 & & & \\
\hline \multicolumn{9}{|c|}{ Dry Matter intake (kg/day) } \\
\hline Pre-calving & $9.51^{\mathrm{b}}$ & $9.58^{\mathrm{b}}$ & $9.60^{\mathrm{b}}$ & $9.61^{\mathrm{b}}$ & 0.12 & $<0.001$ & 0.087 & 0.998 \\
\hline Post-calving & $11.51^{\mathrm{aB}}$ & $11.95^{\mathrm{aA}}$ & $11.98^{\mathrm{aA}}$ & $12.09^{\mathrm{aA}}$ & 0.15 & & & \\
\hline
\end{tabular}

SEM, standard error of the mean; T1, zinc-treated group; T2, vitamin E-treated group; T3, zinc + vitamin E-treated group. Means with different superscripts in small letters in a column and capital letters in row differ significantly $(\mathrm{P}<0.05)$ 
Plasma glucose concentrations began to decrease steadily from $60 \mathrm{~d}$ pre-calving and reached the minimum on the day of calving (Fig. 4). After calving, glucose concentrations started to increase slowly (Fig. 4). This change resulted in lower $(\mathrm{P}<0.05)$ values after calving, compared with those observed before calving in all the groups (Table 2). Plasma concentrations of NEFA began to increase slightly from $30 \mathrm{~d}$ before calving and reached maximum levels on $7 \mathrm{~d}$ post-calving, were higher $(\mathrm{P}<0.05)$ in the control than in the $\mathrm{Zn}$, Vit-E, and $\mathrm{Zn}+$ Vit-E supplemented groups of cows (Fig. 5). After $7 \mathrm{~d}$ post-calving NEFA concentrations started to decrease in all the groups, but the decrease was lower in the control followed by the Zn, Vit-E, and Zn+Vit-E supplemented groups (Fig. 5). The pre-calving plasma NEFA concentration was higher $(\mathrm{P}<0.05)$ than its post-calving concentration in all four groups of crossbred cows (Table 2). The DMI during the precalving period was lower $(\mathrm{P}<0.05)$ than its values observed during post-calving in all four groups (Table 2).

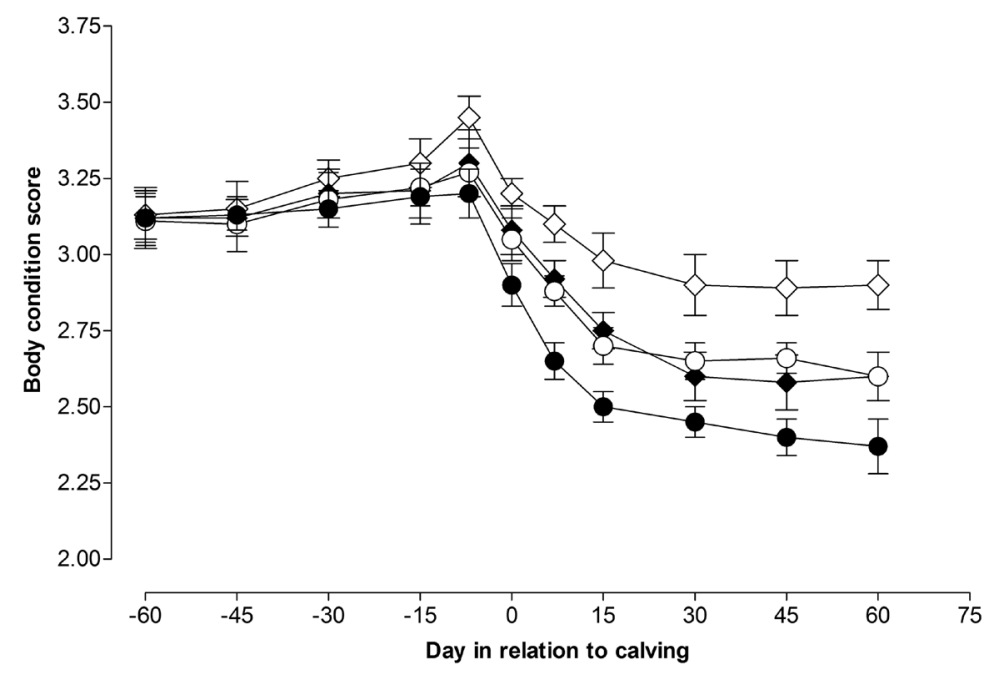

Fig.1. Changes in body condition score during peripartum in control $(\bullet), T 1$ (zinc treated, ○), T2 (vitamin E treated, $\bullet$ ), T3 (zinc + vitamin E treated, $\diamond)$ groups

Plasma Vit-E and Zn levels decreased towards calving and lowest $(\mathrm{P}<0.05)$ on $7 \mathrm{~d}$ post-partum in all the groups (Fig. 6 and 7). The pattern of decreasing Vit-E plasma levels was lower $(\mathrm{P}<0.05)$ towards calving in Vit-E and $\mathrm{Zn}+\mathrm{Vit}-\mathrm{E}$ fed groups in comparison with the control and $\mathrm{Zn}$ fed groups, whereas the pattern of decreasing $\mathrm{Zn}$ plasma was lower $(\mathrm{P}<0.05)$ in the $\mathrm{Zn}$ and $\mathrm{Zn}+\mathrm{Vit}-\mathrm{E}$ fed groups. Pre- and post-calving plasma Vit-E levels were higher $(\mathrm{P}<0.05)$ in the Vit-E and $\mathrm{ZN}+$ Vit-E supplemented groups than in the control and $\mathrm{Zn}$ fed groups of cows (Table 2). Pre- and post-calving plasma $\mathrm{Zn}$ levels were 
A. Aggarwal and G. Chandra: Hormonal, metabolic and productive performance of cows

higher $(\mathrm{P}<0.05)$ in the $\mathrm{Zn}$ and $\mathrm{Zn}+$ Vit-E supplemented groups than in the control and Vit-E groups of cows (Table 2).

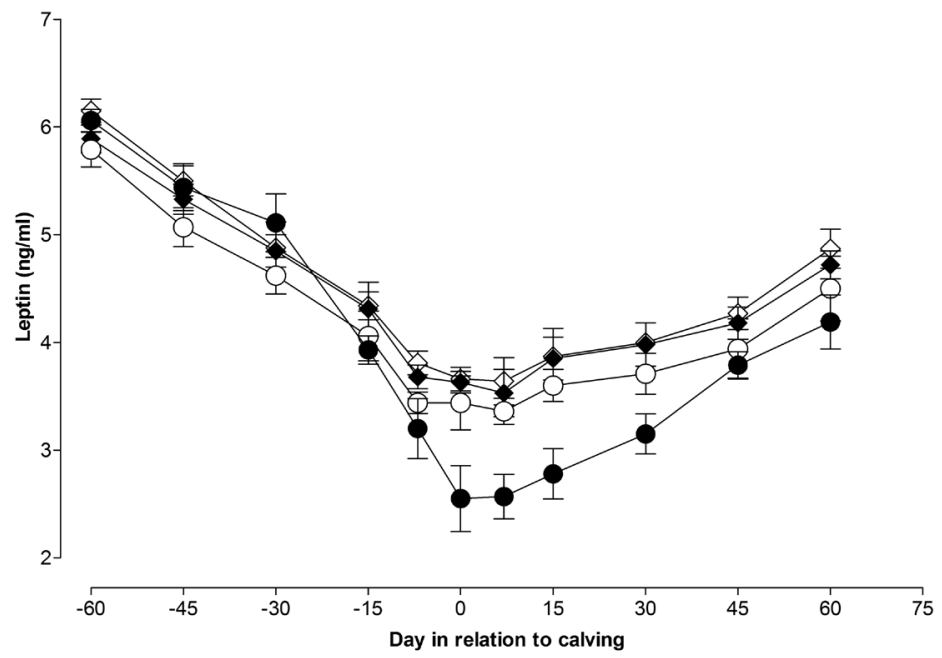

Fig. 2. Changes in plasma leptin level during peripartum in control (•), T1 (zinc treated, o), T2 (vitamin E treated, $\diamond$ ), T3 (zinc + vitamin E treated, $\diamond)$ groups

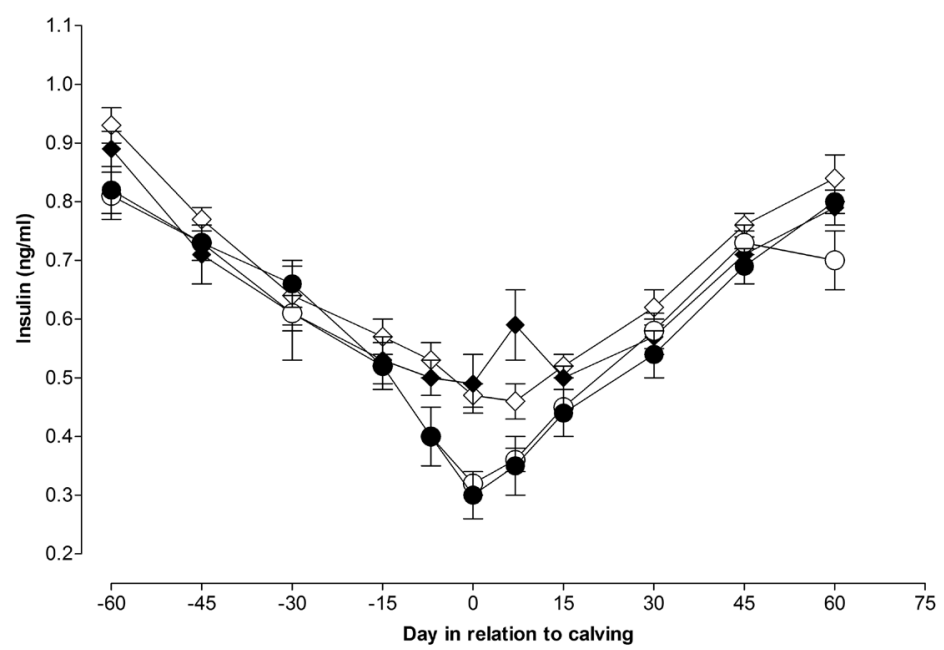

Fig. 3. Changes in plasma insulin level during peripartum in control (•), T1 (zinc treated, o), T2 (vitamin E treated, $\diamond$ ), T3 (zinc + vitamin E treated, $\diamond)$ groups 
A. Aggarwal and G. Chandra: Hormonal, metabolic and productive performance of cows

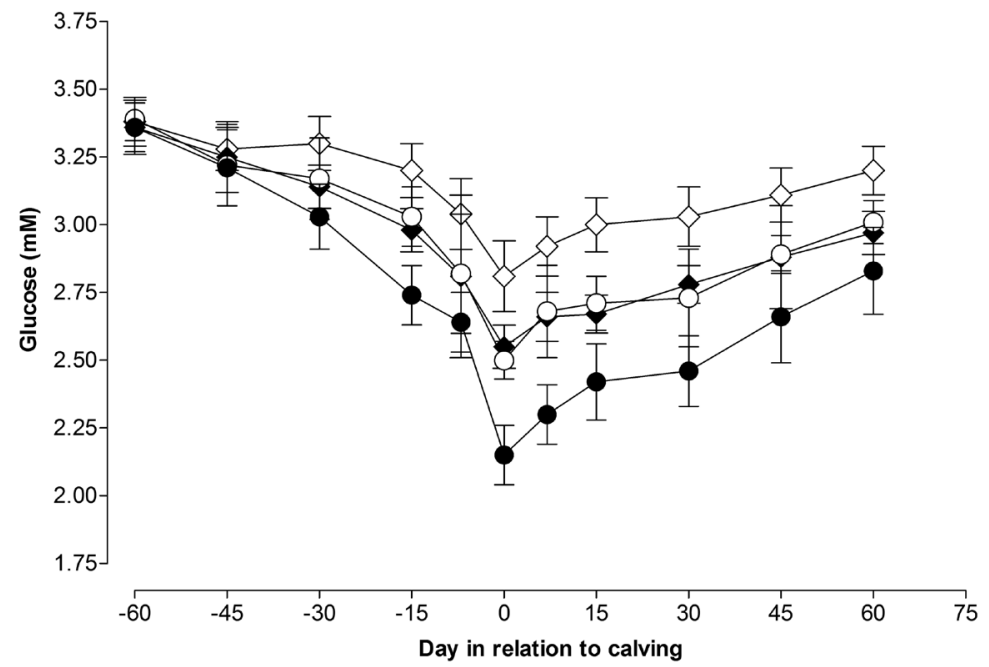

Fig. 4. Changes in plasma glucose level during peripartum in control $(\bullet), \mathrm{T} 1$ (zinc treated, o), T2 (vitamin E treated, $\diamond)$, T3 (zinc + vitamin E treated, $\diamond)$ groups

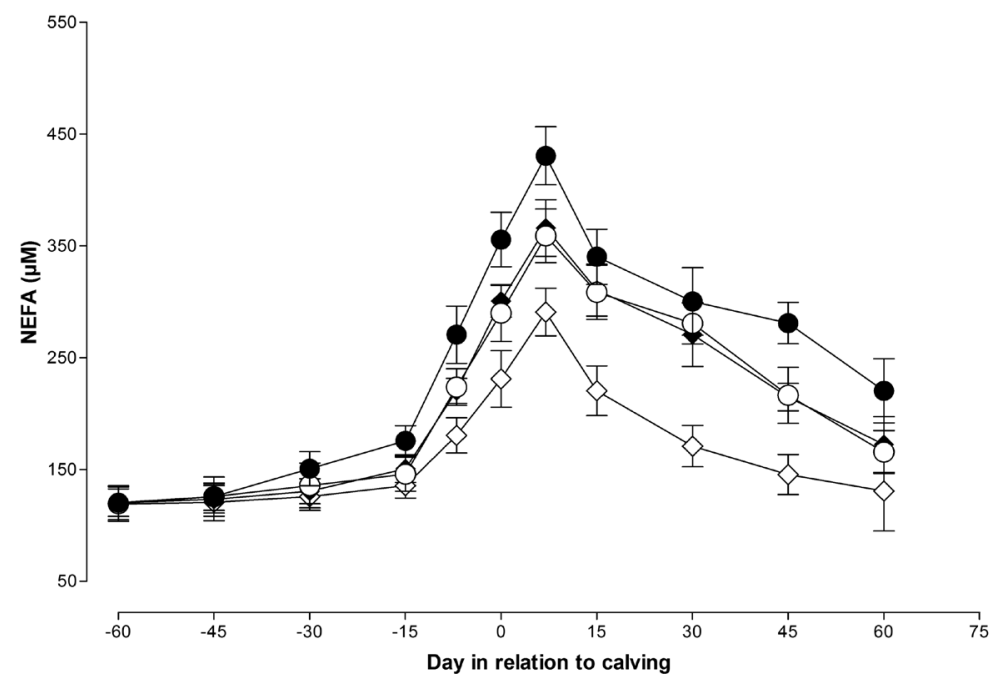

Fig. 5. Changes in plasma non esterified fatty acid (NEFA) level during peripartum in control $(\bullet)$, T1 (zinc treated, ○), T2 (vitamin E treated, $\diamond)$, T3 (zinc + vitamin E treated, $\diamond)$ groups 
A. Aggarwal and G. Chandra: Hormonal, metabolic and productive performance of cows

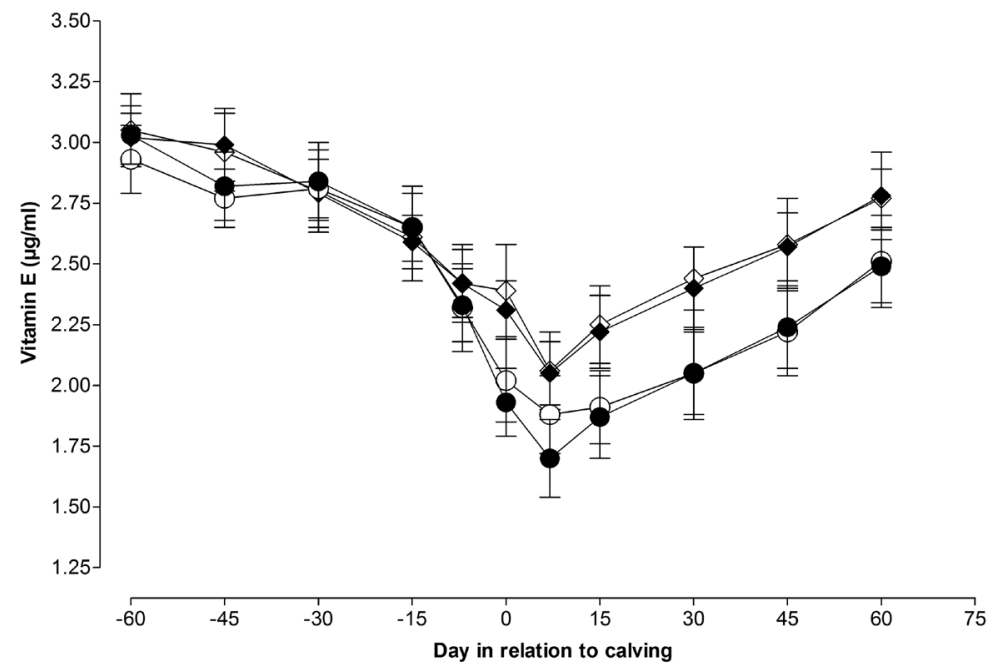

Fig. 6. Changes in plasma vitamin E level during peripartum in control (•), T1 (zinc treated, ○),

T2 (vitamin E treated, $\diamond)$, T3 (zinc + vitamin E treated, $\diamond)$ groups

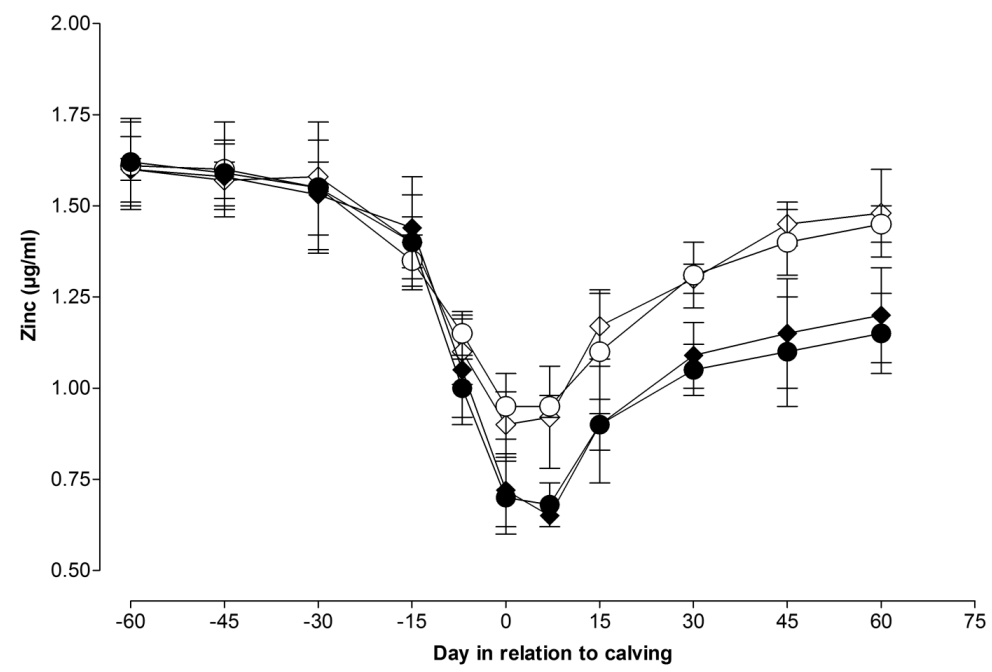

Fig. 7. Changes in plasma zinc level during peripartum in control $(\bullet), \mathrm{T} 1$ (zinc treated, ○), T2 (vitamin E treated, $\diamond)$, T3 (zinc + vitamin E treated, $\diamond)$ groups 
Milk yield was $15.87 \pm 0.56,16.98 \pm 0.57,17.08 \pm 0.63$, and $17.88 \pm 0.49 \mathrm{~kg} /$ day in the control, T1, T2, and T3 groups, respectively. Milk yield was higher $(\mathrm{P}<0.05)$ in the $\mathrm{Zn}+\mathrm{Vit}-\mathrm{E}$ fed group in comparison to the other groups of cows.

\section{Discussion}

Body condition declined in early lactation and continued to decline up to $60 \mathrm{~d}$ postpartum. Similar findings were also noticed by BLOCK et al. (2001) in cows. In accordance with MAURYA (2011), body condition was maintained in the Vit-E and Zn supplemented groups of cows in comparison to cows of in the non-supplemented group. Vitamin E and $\mathrm{Zn}$ are antioxidants that reduce BCS loss around calving, by preventing the breakdown of body reserves that are released in the form of NEFA (BOYLE et al., 2006).

Leptin levels were elevated in the Vit-E and $\mathrm{Zn}$ treated groups in comparison to its levels observed in the other groups. Similarly, MAURYA (2011) observed higher leptin concentrations in Vit-E and $\mathrm{Zn}$ supplemented crossbred cows. The findings of our study on leptin levels are consistent with the findings of BLOCK et al. (2001), who reported that plasma concentrations of leptin decrease during the transition from pregnancy to lactation in dairy cows. There may be reduced synthesis of leptin from white adipose tissues (BLOCK et al., 2001; VILLALOBOS et al., 2007). Supplementation of Vit-E and Zn improved plasma insulin concentrations in crossbred cows (MAURYA, 2011). BLOCK et al. (2001) also reported decreasing plasma insulin concentrations during peripartum The plasma insulin concentrations decreased during peripartum because elevated plasma GH levels attenuate the secretion of insulin from the beta cells of the pancreas (AHIMA and FLIER, 2000). Plasma leptin was positively correlated with plasma insulin (MAURYA, 2011). Insulin is an important regulator of energy homeostasis (MAFFEI et al., 1995).

The decline of glucose concentrations during peripartum was consistent with the findings of MAURYA (2011) in crossbred cows, and CHANDRA et al. (2013) in Sahiwal cows. The lower concentration of plasma glucose during peripartum is due to the fourfold increase in demand for glucose in high yielding lactating dairy cows compared to non-lactating dairy cows (BELL and BAUMAN, 1997). However, decreased DMI around calving may also be a reason for declining glucose during this period (BELL and BAUMAN, 1997). Vitamin $\mathrm{E}$ and $\mathrm{Zn}$ supplementation improved the plasma concentration of glucose, which was also reported by CHANDRA et al. (2013) in Sahiwal cows. The body condition of cows declines around calving and substantial rises in NEFA the in blood reveals body tissue mobilization (BOYLE et al., 2006). In the current study, concentrations of NEFA peaked around calving in all groups, probably because of the low DMI during this period, associated with high energy demand and production of colostrum (SALFER et al., 1995). The lower plasma concentration of NEFA in the Vit-E and Zn treated groups was similar to the findings of MAURYA (2011) in crossbred cows. Dry matter intake decreased near parturition due to the increase in calving stress (CASTILLO 
et al., 2005). Raised DMI in the vitamin E and $\mathrm{Zn}$ supplemented groups during the study period was in accordance with CHANDRA et al. (2013).

Declined plasma concentrations of vitamin E during the transition from late pregnancy to early lactation was similar to that found by GOFF and STABEL (1990) and MEGLIA et al. (2004). During this period plasma Vit-E was 47\% lower (GOFF and STABEL, 1990). This might be due to its loss due to production of colostrum, reduced DMI, and the increased demand for antioxidants (GOFF and STABEL, 1990; MEGLIA et al., 2006). The findings of the present experiment are consistent with GOFF and STABEL (1990) who reported Vit-E supplementation to dry cows raised plasma $\alpha$-tocopherol concentration and helped to restore normal concentrations of plasma Vit-E level.

In line with other studies (GOFF and STABEL, 1990; MEGLIA et al., 2004), the concentration of $\mathrm{Zn}$ declined towards calving. Lower plasma $\mathrm{Zn}$ concentration around caving might be due to colostrogenesis and increased calving stress (GOFF and STABEL, 1990). Stress promotes the formation of metallothionein that is impart in $\mathrm{Zn}$ metabolism which results in the redistribution of Zn from the blood to other tissues (XIN et al., 1993). Supplementation of $Z n$ during the dry period and early lactation enhanced plasma concentrations of Zn, which was also found by CHANDRA et al. (2014) in Sahiwal cows.

Vitamin $\mathrm{E}$ and $\mathrm{Zn}$ supplementation, either alone or together, increased milk production, as was also reported by CHANDRA et al. (2013) in Sahiwal cows. The useful effect of supplementation of Vit-E on milk production has been also documented by CHAWLA and KAUR (2004). In contrast to the present study, BOURNE et al. (2008) and WEISS and SPEARS (2006) observed no significant effect of Vit-E treatment on milk production. KELLOGG et al. (2004) demonstrated that $\mathrm{Zn}$ methionine increased lactation performance. The rise in milk production might be $\mathrm{Zn}$ associated, with cell division and protein synthesis in the udder and teat tissues (SOBHANIRAD et al., 2010).

\section{Conclusion}

Leptin, insulin, glucose, Vit-E, and Zn concentrations were lower, whereas NEFA concentration was higher around calving. Leptin levels were positively correlated with glucose and insulin, and negatively correlated with NEFA. Leptin insulin, glucose, Vit-E, and $\mathrm{Zn}$ concentrations were higher, whereas NEFA concentrations were lower in the Vit$\mathrm{E}+\mathrm{Zn}$ supplemented group than all other groups of cows.

\section{Acknowledgements}

The authors express their sincere thanks to the Hon. Director of National Dairy Research Institute, Karnal for providing the necessary facilities for this work. Financial support was provided by the Department of Biotechnology (DBT) of the Government of India. 
A. Aggarwal and G. Chandra: Hormonal, metabolic and productive performance of cows

\section{References}

AAS (1988): Phillips Scientific Atomic Absorption Data Book, 5 ${ }^{\text {th }}$ ed. Atomic Absorption Spectrophotometry, Phillips Scientific, Cambridge, UK.

AHIMA, R. S., J. S. FLIER (2000): Leptin. Annu. Rev. Physiol. 62, 413-37.

DOI: 10.1146/annurev.physiol.62.1.413

AOAC (Association of Official Analytical Chemists) (1995): Official Methods of Analysis, $16^{\text {th }}$ ed. Association of Official Analytical Chemists, Arlington (Virginia).

BAUMAN, D. E., R. G. VERNON (1993): Effects of exogenous bovine somatotropin on lactation. Annu. Rev. Nutr.13, 437-61.

DOI: 10.1146/annurev.nu.13.070193.002253

BELL, A. W., D. E. BAUMAN (1997): Adaptations of glucose metabolism during pregnancy and lactation. J. Mammary Gland Biol. Neoplasia 2, 265-278.

DOI: $10.1023 / \mathrm{A}: 1026336505343$

BLOCK, S. S., W. R. BUTLER, R. A. EHRHARDT, A. W. BELL, M. E. VAN AMBURGH, Y. R. BOISCLAIR (2001): Decreased concentration of plasma leptin in periparturient dairy cows is caused by negative energy balance. J. Endocrinol. 171, 339-348.

DOI: $10.1677 /$ joe.0.1710339

BOURNE, N., D. C. WATHES, K. E. LAWRENCE, M. MCGOWAN, R. A. LAVEN (2008): The effect of parenteral supplementation of vitamin $\mathrm{E}$ with selenium on the health and productivity of dairy cattle in the UK. Vet. J. 177, 381-387.

DOI: $10.1016 /$ j.tvj1.2007.06.006

BOYLE, N. O., C. M. CORL, J. C. GANDY, L. M. SORDILLO (2006): Relationship of body condition score and oxidant stress to tumor necrosis factor expression in dairy cattle. Vet. Immunol. Immunopath. 113, 297-304.

DOI: 10.1016/j.vetimm.2006.05.013

CASTILlO, C., J. HERnANDEZ, A. BRAVO, M. LOPEZ-AlONSO, V. PEREIRA, J. L. BENEDITO (2005): Oxidative status during late pregnancy and early lactation in dairy cows. Vet. J. 169, 286-292.

DOI: $10.1016 / j . t v j 1.2004 .02 .001$

CHANDRA, G., A. AGGARWAL, A. K. SINGH, M. KUMAR, R. C. UPADHYAY (2013): Effect of vitamin $\mathrm{E}$ and zinc supplementation energy metabolites, lipid peroxidation, and milk production in peripartum Sahiwal cows. Asian-Australas. J. Anim. Sci. 26, 1569-1576.

DOI: 10.5713 /ajas.2012.12682

CHANDRA, G., A. AGGARWAL, M. KUMAR, A. K. SINGH, V. K. SHARMA, R. C. UPADHYAY (2014): Effect of additional vitamin E and zinc supplementation on immunological changes in peripartum Sahiwal cows. J. Anim. Physiol. Anim. Nutr. 98, 1166-1175.

DOI: $10.1111 / j p n .12190$

Vet. arhiv 88 (6), 733-748, 2018 
A. Aggarwal and G. Chandra: Hormonal, metabolic and productive performance of cows

CHAWLA, R., H. KAUR (2001): Isocaratic HPLC method for simultaneous determination of $\beta$-carotene, retinol and $\alpha$-tocopherol in feeds and blood plasma. Indian J. Dairy Sci. 54, 84-90.

CHAWLA, R., H. KAUR (2004): Plasma antioxidant vitamin status of periparturient cows supplemented with $\alpha$-tocopherol and $\beta$-carotene. Anim. Feed Sci. Technol. 114, 279-285.

DOI: 10.1016/j.anifeedsci.2003.11.002

EDMONDSON, A. J., I. J. LEAN, L. D. WEAVER, T. FARVER, G. WEBSTER (1989): A body condition scoring chart for Holstein dairy cows. J. Dairy Sci. 72, 68-78.

DOI: $10.3168 /$ jds.S0022-0302(89)79081-0

FRIGGENS, N. C., K. L. INGVARTSEN, G. C. EMMANS (2004): Prediction of body lipid change in pregnancy and lactation. J. Dairy Sci. 87, 988-1000.

DOI: $10.3168 /$ jds.S0022-0302(04)73244-0

GOFF, J. P., J. R. STABEL (1990): Decreased plasma retinol, a-tocopherol, and Zn concentration during the periparturient period: effect of milk fever. J. Dairy Sci. 73, 3195-3199.

DOI: $10.3168 /$ jds.S0022-0302(90)79010-8

GRUMMER, R. R., D. G. MASHEK, A. HAYIRLI (2004): Dry matter intake and energy balance in the transition period. Vet. Clin. North Am. Food Anim. Pract. 20, 447-470.

DOI: $10.1016 /$ j.cvfa.2004.06.013

HERDT, T. H., H. D. STOWE (1991): Fat-soluble vitamin nutrition for dairy cattle. Vet. Clin. North Am. Food Anim. Pract. 7, 391-415.

DOI: $10.1016 /$ S0749-0720(15)30796-9

KELLOGG, D. W., D. J. TOMLINSON, M. T. SOCHA, A. B. JOHNSON (2004): Review: Effects of zinc methionine complex on milk production and somatic cell count of dairy cattle: twelvetrial summary. Proceeding Anim. Sci. 20, 295-301.

DOI: $10.15232 / \mathrm{S} 1080-7446(15) 31318-8$

MAFFEI, M., J. L. HALAAS, E. RAVUSSIN, R. E. PRATLEY, G. H. LEE, Y. ZHANG, H. FEI, S. KIM, R. LALLONE, S. RANGANATHAN, P. A. KERN, J. M. FRIEDMAN (1995): Leptin levels in human and rodent: Measurement of plasma leptin and ob RNA in obese and weightreduced subjects. Nat. Med. 1, 1155-1161.

DOI: $10.1038 / \mathrm{nm} 1195-1155$

MAURYA, P. (2011): Leptin level in relation to immunity, energy metabolites and cellular adoptations during dry period and early lactation in crossbred cows. MVSc. Thesis, National Dairy Research Institute, Karnal, Haryana, India.

MegliA, G. E., K. HOLTENiUS, L. PETERSSON, P. OHAGEN, W. K. PERSSON (2004): Prediction of vitamin A, vitamin E, selenium and zinc status of periparturient dairy cows using blood sampling during the mid dry period. Acta Vet. Scand. 45, 119-128.

DOI: 10.1186/1751-0147-45-119 
A. Aggarwal and G. Chandra: Hormonal, metabolic and productive performance of cows

MEGLIA, G. E., S. K. JENSEN, C. LAURIDSEN, K. PERSSON WALLER (2006): $\alpha$-Tocopherol concentration and stereoisomer composition in plasma and milk from dairy cows fed natural or synthetic vitamin E around calving. J. Dairy Res. 73, 227-234.

DOI: $10.1017 / \mathrm{S} 0022029906001701$

NRC (2001): Nutrient Requirements of Dairy Cattle, $7^{\text {th }}$ ed. National Academy Press, Washington D.C. (USA).

PEZEShKI, A., A. V. CAPUCO, B. DE SPIEGELEER, L. PEELMAN, M. STEVENS, R. J. COLLIER, C. BURVENICH (2010): Review: An integrated view on how the management of the dry period length of lactating cows could affect mammary biology and defense. J. Anim. Physiol. Anim. Nutr. 94, 7-30.

DOI: 10.1111/j.1439-0396.2010.00991.x

SALFER, J. A., J. G. LINN, D. E. OTTERBY, W. P. HANSEN, D. G. JOHNSON (1995): Early lactation responses of holstein cows fed a rumen-inert fat prepartum, postpartum, or both. J. Dairy Sci. 78, 368-377.

DOI: $10.3168 /$ jds.S0022-0302(95)76645-0

SOBHANIRAD, S., D. CARLSON, R. B. KASHANI (2010): Effect of zinc methionine or zinc sulfate supplementation on milk production and composition of milk in lactating dairy cows. Biol. Trace Elem. Res. 136, 48-54.

DOI: $10.1007 / \mathrm{s} 12011-009-8526-3$

THORN, S. R., R. A. EHRHARDT, W. R. BUTLER, S. M. QUIRK, Y. R. BOISCLAIR (2008): Insulin regulates hepatic leptin receptor expression in early lactating dairy cows. Am. J. Physiol. Regul. Integr. Comp. Physiol. 295, R1455-R1462.

DOI: 10.1152/ajpregu.90546.2008

UNDERWOOD, E. J., N. F. SUTTLE (2001): The Mineral Nutrition of Livestock, $3^{\text {rd }}$ ed. CABI Publishing, CAB International, Wellingford, UK.

VAN SOEST, P. J., J. B. ROBERTSON, B. A. LEWIS (1991): Methods for dietary fiber, neutral detergent fiber and non-starch polysaccharides in relation to animal nutrition. J. Dairy Sci. 74, 3583-3597.

DOI: $10.3168 /$ jds.S0022-0302(91)78551-2

VILLALOBOS, D. B., I. G. TORNADU, G. SHROEDER, E. E. SALADO, G. GAGLIOSTRO, C. DELAVAUD, Y. CHILLIARD, I. M. LACAU-MENGIDO (2007): Effect of fat supplementation on leptin, insulin-like growth factor I, growth hormone, and insulin in cattle. Can. J. Vet. Res. 71, 218-225.

WEISS, W. P. (2002): Relationship of mineral and vitamin supplementation with mastitis and milk quality. In: Proc. Annual Meeting, National Mastitis Council, Orlando, Florida, USA, pp. 3744.

WEISS, W. P., J. W. SPEARS (2006): Vitamin and trace mineral effects on immune function of ruminants. In: Ruminant Physiology. (Sejrsen, K., T., Hvelplund, M. O. Nielsen, Eds.) Wageningen Academic Publishers, Utrecht, The Netherlands, pp. 473-496. 
A. Aggarwal and G. Chandra: Hormonal, metabolic and productive performance of cows

XIN, Z., D. F. WATERMAN, R. W. HEMKEN, R. J. HARMON (1993): Copper status and requirement during the dry period and early lactation in multiparous Holstein cows. J. Dairy Sci. 76, 2711-2716.

DOI: $10.3168 /$ jds.S0022-0302(93)77607-9

Received: 19 August 2017

Accepted: 20 September 2018

\section{AGGARWAL, A., G. CHANDRA: Endokrine i metaboličke promjene u mliječnih krava tijekom peripartalnog razdoblja uzrokovane dodatkom vitamina $\mathbf{E}$ i cinka $\mathbf{u}$ prehrani. Vet. arhiv 88, 733-748, 2018.}

\section{SAŽETAK}

Cilj ovoga istraživanja bio je izmjeriti učinak vitamina E i cinka (Zn) na endokrine i metaboličke promjene u krava tijekom peripartalnog razdoblja. U istraživanje su uključene 32 krave, križanke (Holstein-Friesian $\times$ Tharparkar), 60 dana prije očekivanog teljenja. Krave su nasumce podijeljene u četiri skupine $(n=8)$ : kontrolnu skupinu, T1, T2 i T3. Hranidbeni je protokol bio sličan u svim skupinama, osim što je skupinama T1, T2 i T3 dodano $60 \mathrm{mg} \mathrm{Zn/kg} \mathrm{suhe} \mathrm{tvari,} 1000$ i. j. vitamina $\mathrm{E}$ te $60 \mathrm{mg} / \mathrm{kg}+1000$ i. j. Zn + vitamin E, pojedinačno, od 60. dana prije teljenja do 60. dana poslije teljenja. Krv je uzeta 60., 45., 30., 15. i 7. dan prije očekivanog teljenja, na dan teljenja te 60., 45., 30., 15. i 7. dan poslije teljenja. Prije teljenja krave su pokazale smanjenje razine leptina, inzulina, glukoze, vitamina E i cinka te povećanje razine neesterificirane masne kiseline u plazmi. Nakon teljenja razine leptina, inzulina, glukoze, vitamina E i cinka porasle su, a razina neesterificirane masne kiseline u plazmi bila je snižena. Nakon teljenja skupina T3 imala je povišene vrijednosti $(\mathrm{P}<0,01)$ leptina, inzulina i glukoze u odnosu na ostale skupine. Razina vitamina $\mathrm{E}$ u plazmi bila je veća $(\mathrm{P}<0,01)$ u skupinama T2 i T3; razina cinka bila je veća u skupinama T1 i T2. U skupini T3 opažena je viša $(\mathrm{P}<0,01)$ količina mlijeka u odnosu na kontrolnu skupinu, skupine T1 i T2. Snižavanje razine leptina, inzulina, glukoze, vitamina E i cinka u peripartalnom razdoblju ublaženo je dodacima vitamina E i cinka u prehrani.

Ključne riječi: leptin; inzulin; vitamin E; cink; krave križanke 